\title{
Güzel Sanatlar Ĕgitimi Bölümü Öğrencilerinin Meslek Dersleri ve Öğretim Elemanlarına İlişkin Görüşleri ${ }^{1}$
}

\section{Views of Fine Arts Education Department Students with Teacher Professional Courses and Instructors}

\section{Anahtar Kelimeler Öğretmen adayl, Ögretmenlik meslek dersleri, \\ Öğretim elemanları, Mesleki tutum.}

\author{
İbrahim GÜL ${ }^{2}$ Yüksek GÜNDÜZ ${ }^{3}$
}

\begin{abstract}
$\ddot{O} z e t$
Ögrretmenlik meslek dersleri, ögretmen adaylarını mesleğe hazırlayan derslerdir. Bu dersler, eğitim fakültelerinin farkl bölümlerinde mesleğe hazırlık amacıyla okutulmaktadırlar. Buna ilişkin yapılan araştırmanın amacı, güzel sanatlar bölümü ögrrencilerinin meslek derslerine ve ögretim elemanlarına yönelik görüşlerini ortaya çıkarmaktır. Araștırma nitel bir çalıșmadır. Araștırmanın çalıșma grubunu, Ondokuz Mayıs Üniversitesi, Güzel Sanatlar Eğitimi Bölümünde okuyan resim-iş ve müzik ögretmenliğinde öğrenim gören 67 ögrenci oluşturmaktadır. Araştırma bulgularının çözümlenmesinde nitel analiz yöntemlerinden betimsel ve içerik analizi yöntemleri kullanılmıștır. Araștırma bulgularına göre, katılımcıların çoğunluğunun (34) meslek derslerine ilişkin olumlu bir tutum içinde olmadıkları, buna karşın bir kısım katılımcinin (28) olumlu görüş içinde olduklarl görülmüştür. Diğer bulguda, ögretmen adaylarının büyük bir kısmı (37) ögretim elemanlarını uygulamaları yönünden olumsuz olarak değerlendirirken, az bir kısmı da (8) olumlu olarak değerlendirmişlerdir. Bu sonuçlara göre, meslek derslerinin, öğretmen adaylarının ilgi ve ihtiyaçlarına göre düzenlenmesi ve meslek derslerini veren ögretim elemanlarinin daha duyarl ve olumlu davranmaları gerekmektedir. Farklı fakültelerde benzer çalıșmalar yapılarak sonuçları karșılaștırılmalıdır.

\section{Abstract}

Pedagogical courses prepare candidates teacher for their profession. These courses are taught in different sections of the faculties of education to prepare them for their profession. The aim of this research is to investigate the opinions of the students of the arts department towards the professional courses and instructors. The research is a qualitative study. The study group consisted of 67 students studying at Ondokuz Mayls University, Fine Arts Education Department. Descriptive and content analysis methods are used in the analysis of research data. According to the findings of the study, it was found that most of the participants (34) do not have a positive attitude toward the pedagogical courses, whereas some of the participants (28) were in a positive opinion., a large number of teacher candidates (37) evaluated the their instructors as negative in terms of their practices, and a small percentage (8) considered them in a positive perspective. According to these results, the vocational courses should be arranged according to the interests and needs of the prospective teachers and the instructors who give the vocational courses should be more sensitive and positive toward them. Similar studies should be done in different faculties and their results should be compared.
\end{abstract}

$\underline{\text { Key Word }}$

Teacher candidate, Pedagogical courses Instructors,

Professional attitude,

\footnotetext{
Atıf için:

Gül, İ. \& Gündüz, Y. (2020). Güzel Sanatlar Eğitimi Bölümü Öğrencilerinin Meslek Dersleri For Citation ve Öğretim Elemanlarına İlişkin Görüşleri. Muğla Sitkı Koçman Üniversitesi Eğitim Fakültesi Dergisi [MSKU Journal of Education], 7(1), 62-70. DOI: 10.21666/muefd.517529

Received: 24.01.2019 Accepted: 16.03.2020 Published: 01.05.2020

${ }^{1}$ Bu çallş̧ma 10-12 Mayıs 2018 tarihleri arasında 13. Uluslararası Eğitim Yönetimi Kongresinde özet bildiri olarak sunulmuştur.

${ }^{2}$ Ondokuz Mayıs Üniversitesi, Eğitim Fakültesi, igul@omu.edu.tr, Orcid No: 0000-0002-0501-8221

${ }^{3}$ Ondokuz Mayıs Üniversitesi, Eğitim Fakültesi, yuksel.gunduz@omu.edu.tr, Orcid No: 0000-0002-4710-8444
} 
Öğretmenlik en eski mesleklerden birisi olup, halen önemini korumaktadır. Bu mesleğin önemi insan yetiştirmesinden kaynaklanmaktadır. Ülkenin siyasal rejimini koruyan, içinde yaşadığı toplumla bütünleşen, ülkenin insan kaynaklarını yetiştirenler öğretmenlerdir. Bu bağlamda düşünüldüğünde, öğretmen bir ülkenin geleceğinin mimarıdır (Çelikten, Şanal ve Yeni, 2005: 208). Bu bakımdan öğretmenlik mesleği bir ülkenin geleceği bakımından önemli meslekler arasında yer almaktadır.

M. Kemal Atatürk'ün belirttiği gibi, "Milletleri kurtaranlar yalnız ve ancak öğretmenlerdir" (Akyüz, 1989: 375). Öğretmenlik mesleğini isteyerek seçen öğretmen adaylarının geleceğine yönelik bakış açılarının olumlu olduğu bazı araştırmalarda dile getirilmektedir (Bozdoğan, Aydın ve Yıldırım, 2007; Bursal ve Buldur, 2016; Ünal ve Şimşek, 2008). Öğretmenin kalitesi, onların almış oldukları hizmet öncesi eğitimin nitelik ve kalitesine bağlı olarak değişmektedir. Başka bir anlatımla, değişen dünyaya uyum sağlamak, çağdaş bir eğitimi gerektirmekte, bu çağdaş eğitimi verecek öğretmenlerin de çağdaş bir yaklaşımla yetiştirilmeleri beklenmektedir (Köksal, 2008: 37).

Milli Eğitim Temel Kanununda öğretmenlik mesleği özel bir ihtisas mesleği olarak tanımlanmıștır. Bu bağlamda öğretmenlerin üç temel alanda lisans eğitimi almaları zorunludur (MEB, 1973). Bu kapsamda, eğitim fakültelerinde öğretmen adaylarına üç farklı yeterlilik alanında eğitim verilmektedir. $\mathrm{Bu}$ alanlar genel kültür, özel alan bilgisi ve meslek bilgisidir (Varış, 1988: 119). Meslek dersleri, öğretmen adaylarını mesleğe hazırlayan önemli bir alanı içermektedir. Bu bakımdan öğretmen adaylarının meslek derslerine karşı tutumlarının ortaya çıkarılması önemlidir.

Öğretmenlik meslek derslerine karşı öğrencilerin tutumlarını ortaya çıkarmaya yönelik farklı çalışmalar yapılmıştır. Çetin (2009) ile Aydın ve Sağlam'ın (2012) araştırmalarında, öğretmenlik meslek derslerine karşı tutum puanları cinsiyete göre farklılaşmış, kız öğrencilerin istenen yöndeki tutum puanları erkek öğrencilere oranla yüksek bulunmuştur. Terzi ve Tezci (2007) öğrencilerin meslek derslerine yönelik tutumlarını yüksek bulmuşlardır. Özgüngör ve Kapıkıran (2008) güzel sanatlar öğrencilerinin meslek derslerine karşı tutumlarını, diğer bölümlere göre düşük bulmuşlardır. Aladağ ve Buldur'ın (2016) araştırmasında, coğrafya öğretmen adaylarının bazıları meslek bilgisi derslerinin gereksiz olduğunu belirtmişlerdir. Bulut'un (2009) çalışmasında ise öğretmen adaylarının ögretmenlik mesleğine yönelik tutumları olumlu bulunmuştur. Ancak bu tutum anabilim dallarına göre farkl11ık göstermektedir. Işıkgöz vd (2016) beden eğitimi öğretmenlerinin meslek dersleri tutumunu alan derslerine göre düşük bulmuşlardır. Gül'ün (2017) araştırmasında, genel olarak eğitim fakültesi öğrencilerinin meslek derslerine karşı tutumları düşük bulunmuştur.

Öğretmenlerin mesleki tutumları, onların mesleği etkili olarak yapmasına yardım eden hususların başında gelmektedir (Erdem, Gezer ve Çokadar, 2005). Tutumlar mesleklerin en önemli belirleyicilerinden birisi olarak görülür. Daha okul sıralarında öğretmenliğe ilgi duyan adayların öğretmen olduktan sonra da işini severek yapması beklenir. Öğretmen adaylarının meslek derslerine karşı tutumlarını belirleyen önemli hususlar şunlardır: Öğretim elemanları, derslerin içeriği, sınıfların kalabalık olması, öğrencilerin ilgisi, alanla ilgisinin bulunması.

Eğitim fakültelerinde görevli öğretim üyeleri, öğrencilerin meslek derslerine yönelik tutumlarını etkileyen önemli hususlardan birisi olarak görülmektedir. Gül (2017) araştırmasında, öğretim elemanları davranışları meslek derslerine tutumun bir yordayıcısı olarak bulmuştur. Dolayısıyla öğretim elemanlarının tutum ve davranışları, öğrenciler üzerinde önemli bir etkiye sahip olduğu söylenebilir. Bu açıdan bakıldığında, öğrencilerin öğretim elemanlarından bir takım beklenti içinde oldukları görülmektedir. Öğrenciler iyi bir öğreticide bulunması gereken özellikleri; alana hâkim, genel öğretim yeterliklerine sahip, iyi iletişim kuran, doğru yöntem, strateji ve araç kullanma becerisine sahip, bilginin nasıl aktarılacağını bilen, öğrencilerle işbirliği kurabilen kişiler olarak tanımlamaktadırlar (Şen ve Erişen, 2002: 114). Türkoğlu (1993) ve Yüksel'in (2004) araştırmalarında, öğretim elemanları kendilerini yeterli görürken, öğrencilerin yetersiz gördükleri ortaya konmuştur.

Öğretim elamanları meslek derslerini öğrencilere sevdirebilecekleri gibi onların bu derslere ilgisiz kalmalarına zemin de hazırlayabilirler. Diğer taraftan öğretim elemanları, öğretmen adayları için rol model görevi üstlenmişlerdir. Onlara davranışlarıyla örnek olurlar. Aksu, Çivitçi ve Duy'un (2008) araştırmasında, birinci öğretim öğrencileri öğretim elemanlarını olumsuz değerlendirirken, özel yetenekle öğrenci alan (Güzel sanatlar gibi) bölüm öğrencileri daha olumlu değerlendirmişlerdir. Bayram (1992), Deryakulu, (1992), Bolat (1992) ve Erdoğan'ın (1990) araştırmalarında, öğretim elamanları öğrenciler tarafından olumsuz olarak değerlendirilmişlerdir.

Meslek dersleri, öğretmen adaylarını mesleğe hazırlayan derslerin önemli bir bölümünü oluşturmaktadır. Bir bakıma alan bilgisi derslerindeki bilgilerini uygulamaya yönelik bilgiler içerir 
(YÖK, 2007). Öğretmen adayları öğretmenlik meslek bilgisi derslerinde öğrenmiş oldukları kuramsal bilgileri uygulamaya dönüştürebilirlerse verilen eğitim amacına ulaşmış olur (Sılay ve Gök, 2004). Meslek dersleri; eğitim bilimine giriş, öğretim ilke ve yöntemleri, sınıf yönetimi, eğitimde ölçme ve değerlendirme, rehberlik, özel öğretim yöntemleri, okul deneyimi, öğretmenlik uygulaması gibi derslerden oluşmaktadır (Ekici, 2008). Bu dersler öğretmen adaylarını mesleğe hazırlayan ve onların profesyonel gelişimlerine katkı sağlayan dersler arasında yer almaktadırlar. Bir araştırmada, sınıf öğretmenliği ve okulöncesi öğretmen adayları bu derslerin profesyonel gelişimlerini olumlu yönde etkilediklerini bildirmişlerdir (Taşkın ve Hacıömeroğlu, 2010).

Öğrencilerin meslek derslerine karşı olumsuz tutum geliştirmelerine neden olan faktörler arasında, ögretmenlerin ders anlatma yöntemleri de bulunmaktadır. Derslerin işlenmesinde etkili yöntem ve tekniklerin kullanılmaması, bu derslere olan ilgiyi azaltmaktadır. Taşkın ve Hacıömeroğlu'nun (2010), bulguları bu doğrultudadır. Öğretmenlik meslek bilgisi (ÖMB) derslerinin verimli ve etkili işlenmesi, meslek derslerine karşı tutumu olumlu yönde etkileyecektir (Yüksel, 2009). ÖMB derslerinde kazandırılması gereken davranışların açı hale getirilmesi ve öğretmen adaylarında farkındalık sağlanması önemli görülmüştür (Kara ve Sağlam, 2014).

Bunlara ilave olarak öğretmen adaylarının meslek derslerine karşı tutumlarını etkileyen önemli faktörlerden birisi de fiziksel düzenlemelerdir. Fiziksel düzenlemeler arasında sınıfların kalabalık olması, oturma düzeni, sınıfın 1s1, 1şık vb. özellikleri gelmektedir. Buyurgan'ın (2007) resim öğretmenliği öğrencileri üzerine yaptığı bir araştırmada, öğrenciler fiziki donanım, ders isim ve saatleri, öğretim elemanlarının niteliği ve tutumu ile sınav sistemi gibi özelliklerin iyileştirilmesini istemişlerdir.

Buraya kadar yapılan açıklamalardan öğretmenlerin meslek derslerine olan tutumunun onların ileriki yıllarda mesleklerini etkili olarak yerine getirmelerinde ne kadar önemli olduğunu göstermektedir. $\mathrm{Bu}$ araştırmanın amacı güzel sanatlar bölümü öğrencilerinin meslek dersleri ve o dersleri veren öğretim elemanları ile ilgili görüşlerini ortaya çıkarmaktır.

\section{Yöntem}

\section{Araştırmanın Modeli}

Bu araştırma nitel bir çalışmadır. Nitel çalışmalar, üründen çok sürece odaklanmaktadır. Bu bakımdan nitel çalışmalarda anlamlar önem taşımaktadır (Merriam, 1988: Akt. Yılmaz ve Altınkurt, 2011). Nitel araştırma desenleri araştırmacıya esnek bir yaklaşım sağlar ve belirli bir odak çerçevesinde çeşitli aşamalarının birbiriyle tutarlı olmasına katkıda bulunur (Patton, 1987, Akt. Yıldırım ve Şimşek, 2008).

Güzel sanatlar eğitimi öğrencilerinin meslek derslerine ve öğretim elemanlarına yönelik görüşlerinin açık olarak ortaya konmasını amaçlayan araştırmaya bu model daha uygun düşmektedir. Bu görüşlere dayalı olarak derinlemesine bir analiz yapılabilecektir. Öğrencilerin meslek derslerine yönelik olumlu ve olumsuz görüşleri nelerdir ve öğretim elemanları hakkında neler düşünmektedirler sorularının cevabı daha ayrıntılı olarak ortaya çıkarılacaktır.

\section{Çalışma Grubu}

Araştırmanın çalışma grubunu, 2017-2018 eğitim öğretim yılında Ondokuz Mayıs Üniversitesi, Eğitim Fakültesi, Güzel sanatlar bölümünde öğrenim gören ve amaçlı örneklem yöntemi ile seçilen 67 dördüncü sınıf öğrencisi oluşturmaktadır. Araştırmaya katılan öğrencilerin 56'1 resim-iş, 11'i ise müzik bölümünde öğrenim görmektedir. Amaçlı örnekleme zengin bilgiye sahip olduğu düşünülen durumların derinlemesine çalışılmasına olanak verdiği için tercih edilmiştir.

\section{Veri Toplama Araci}

Araştırmada veri toplama amacıyla araştırmacılarca geliştirilen ve iki sorudan oluşan yarı yapılandırılmış görüşme formu kullanılmıştır. Bu sorularda öğrencilere meslek derslerine ve bu derslere giren öğretim elemanlarına ilişkin olumlu ve olumsuz görüşlerini yazmaları istenmiştir. Hazırlanan görüşme formu alanında uzman 2 öğretim üyesine inceletilmiş, verilen dönütler doğrultusunda gerekli düzeltmeler yapılmıştır. Düzeltmesi yapılan bu form 5 öğrenciye okutulmuş, anlamadıkları ya da kavram kargaşasına yol açan sorular bulunup bulunmadığı saptanmıştır. Gerekli düzeltmelerden sonra form uygulama aşamasına gelmiştir. Nitel araştırmada geçerlik, araştırmacının 
araştırdığı olguyu, olduğu biçimiyle ve olabildiğince yansız gözlemesi anlamına gelmektedir (Kirk ve Milller, 1986, Akt. Yıldırım ve Şimşek, 2008). Bu yönüyle formun geçerliliği sağlanmıştır.

Katılımcılar ile yapılan görüşmeler 15 dakika ile 20 dakika arasında değişiklik göstermiştir. Görüşme yöntemi, katılımcılara kendi bakış açılarından cevap verme firsatı vermektedir. Anketlerde olduğu gibi önceden hazırlanmış sorular olmadığı için katılımcılar serbestçe bir konu üzerinde düşüncelerini açıklayabilmektedirler (Bogdan ve Biklen, 1998). Görüşme yardımıyla veri toplanması sırasında katılımcıların değişik ve zengin fikirleri sunmalarına olanak sağlanmış, katılımcıların görüşleri herhangi bir şekilde sınırlandırmaya tabi tutulmamıştır.

\section{Verilerin Analizi}

$\mathrm{Bu}$ araştırmada verilerin çözümlenmesinde "betimsel analiz" ve "içerik analizi" yöntemlerinden yararlanılmıştır. Veriler dört aşamada analiz edilmiştir: Önce veriler kodlanmış ve kodlanan verilere iliş̧in temalar belirlenmiştir. Kodların ve temaların düzenlenmesi işini bulguları tanımlama ve yorumlama aşaması izlemiştir (Yıldırım ve Şimşek, 2008: 228). Yazıya dökülen verilerin aslına tamamen sadık kalınmıştır. Her katılımcının belirttiği görüşler iki üç defa gözden geçirilmiş ve belirtilenlerin doğruluğu iki araştırmacı tarafından teyit edilmiştir. Çalışmada katılımcıların görüşleri realist mod kullanılarak sunulmuştur (Creswell, 2002; Van Maanen, 1988). Böylelikle, araştırmacılar, katılımcıların görüşlerine karşı tarafsız kalmışlar ve onların konu hakkındaki görüşlerini serbestçe paylaşmalarına izin vermişlerdir. Araştırmacılar, katılımcıların görüşlerini, düşünce bütünlüğünün bozulmaması ve okurun kendi yorumunu yapabilmesi için özellikle kısaltmadan vermişlerdir. Görüşler analiz edilirken öğrencilere (ÖA1, ÖA2, ÖA3) kod numaras1 verilmiştir. Elde edilen veriler gruplanarak frekans olarak ifade edilmiştir. Benzer öğeler gruplandırılarak temalar elde edilmiştir. Temalar yorumlanarak bazı sonuçlara ulaşılmaya çalışılmıştır.

\section{Bulgular}

Bulgular bölümünde, öğretmen adaylarının meslek dersleri ve bu derslere giren öğretim elemanlarına ilişkin görüşleri analiz edilerek tablolarda sunulmuştur. Tabloda öğrencinin görüşleri temalara dayalı olarak verilmiş ve bu görüşlere katılan öğrenciler ile bu öğrencilere ait frekans değerler çıkarılmıştır. Her tablonun altında gerekli açıklamalar yapılmış ve bulguları destekleyen doğrudan öğrenci görüşlerine yer verilmiştir.

\section{Öğretmen Adaylarının Meslek Derslerine İlişkin Görüşleri}

Öğretmen adaylarının meslek derslerine ilişkin olumlu, kısmen olumlu ve olumsuz görüşlere ilişkin temalar ve öğrencilere ilişkin kodlamalar Tablo 1'de verilmiştir.

Tablo 1

Ögrretmen Adaylarının Meslek Derslerine İlişkin Görüşleri

\begin{tabular}{|c|c|c|c|}
\hline Temalar & Kodlar & Öğretmen adaylarının görüşleri & $\mathbf{n}$ \\
\hline \multirow{3}{*}{$\begin{array}{l}\text { Olumlu } \\
\text { Görüşler }\end{array}$} & Bazı meslek dersleri iyidir & $1,3,5,6,4,21,24,26,28,29,32,52,53,58$ & 14 \\
\hline & Dersler genel olarak verimli oldu & $10,30,33,34,35,36,37,38,39$ & 9 \\
\hline & Eğitim dersleri önemli derslerdendir & $7,8,18,40,41$ & 5 \\
\hline \multirow{3}{*}{$\begin{array}{l}\text { Kismen } \\
\text { Olumlu } \\
\text { Görüşler }\end{array}$} & Uygulama eksikliği ve tutarsızlıklar var & 23,59 & 2 \\
\hline & Derslere karşı pek olumlu düşüncem yok & $6,15,50,51,56,57$ & 6 \\
\hline & Bazı dersler kaldırılmalı & $46,47,64$ & 3 \\
\hline \multirow{7}{*}{$\begin{array}{l}\text { Olumsuz } \\
\text { Görüşler }\end{array}$} & Bana katkısı olmadı dershaneye gidiyorum & 11,13 & 2 \\
\hline & Başaramayacağım derslerdendir & 43,67 & 2 \\
\hline & Sorumlu olunan konular çok & 63,65 & 2 \\
\hline & $\mathrm{Bu}$ derslerden bir yarar görmedim & $16,17,49,50,57$ & 5 \\
\hline & Kitaplar çok ayrıntılı & 12 & 1 \\
\hline & Dersi anlamiyorum & 44 & 1 \\
\hline & Toplam & & 62 \\
\hline
\end{tabular}


Tablo 1'de öğretmen adaylarının meslek derslerine yönelik görüşlerine bakıldığında, öğretmen adaylarının 14'ü bazı meslek derslerinin iyi olduğunu, 9'u derslerin genel olarak verimli olduğunu, 6'sı derslerin verimli olmadığını, 6'sı dersleri olumlu bulmadığını, 5'i derslerin önemli olduğunu, 5'i derslerden bir yarar görmediğini, 4'ü derslerin yeterli olmadığını, 3'ü kaldırılması gereken derslerden olduğunu, 2'i kendisine bir katkısının olmadığını, 2' başaramayacağ 1 derslerden olduğunu, 2'si konuların çok olduğunu, 1'ikitapların çok ayrıntılı olduğunu ve 1'i de dersi anlayamadığını dile getirdikleri görülmüştür.

Öğretmenlerin görüşleri olumlu görüşler, kısmen önemli görüşler ve olumsuz görüşler olmak üzere üç tema altında ele alınabilir. Bu temalar incelendiğinde olumlu görüşleri oluşturan temaya yönelik frekansların yüksekliği öğretmen adaylarının daha çok olumlu görüşlere sahip olduklarını göstermektedir.

Bazı öğretmen adaylarının meslek dersleri öğretim elamanlarına ilişkin görüşleri olduğu gibi aşağıya çıkarılmıştır:

"Bazı eğitim derslerimiz çok verimli bir şekilde verildi. Hem de hiç zorlanmadan zevk aldığımız dersler oldu. Ama bazı dersler için aynı durum söz konusu değil (ÖA1)."

"Ölçme değerlendirme, sınıf yönetimi dersleri çok iyiydi (ÖA5)."

"Bana bir katkısı olmadı açıkçası. Eğitim dersleri için dershaneye gidiyorum, keşke gerek kalmasaydı (ÖA11)."

"Eğitim dersleri hakkındaki düşüncem hiçbir yararını bu zamana kadar göremedim (ÖA16)."

"Bazı dersler daha verimliydi diğerlerine göre (ÖA 21)."

"Derslerimizde herhangi bir sorun bulamıyorum ÖA30)."

"Çok güzel eğitim dersleri aldık harikaydı bence kendimi öğretmen gibi hissediyorum. Eğer atanırsam çok bir öğretmen olacağımı düşünüyorum adeta bir pedagog gibiyim. Bunu da sevgili öğretmenlerime borçluyum ÖA36)."

"Pek olumlu bir düşüncem yok. Çoğu hocamız bizi derste uyutuyor ÖA 45)."

"Bazı eğitim derslerini yeterince alamadığımı düşünüyorum ÖA 51)."

"Bu eğitim derslerinin olumsuz yönleri çok ağır ve alan dersimiz olmadığı halde alan dersleri gibi değil de daha yüzeysel ve öğretmenlik mesleğini ilgilendirecek şekilde düzenlenip öyle aktarılması daha mantıklıdır ÖA 59).”

"Eğitim derslerinin yetersiz olduğunu düşünüyorum ÖA 62)."

"Diğer dersler not ortalamalarımızı düşürdüğü gibi ezberimizden uçup gitmesi bir oldu ÖA 6)."

"Bazı hocalar sevdirerek öğretiyor bazıları eğitimi işkenceye dönüştürüyor ÖA 15)."

"Dersteki hocaların tam anlamı ile uygun anlattığını düşünmüyorum ÖA 24)."

"KPSS bünyesine uygunu ders verilip sorular çözülse daha verimli olur. Ayrıca final ve vize soruları da

KPSS düzeyine göre olsa daha iyi verim sağlanacağını düşünüyorum ÖA 28)."

"Öğrenilmiş çaresizlik. Sonucu bile bile sınava girmek ÖA 43)."

"Görmüş olduğumuz eğitim dersleri konuların çoğunun sınıf geçmeyi zorlandırdığını düşünüyorum.

Aldığımız gerekli bilgilerin dışında ÖA 50)."

"Materyal bakımından fazlasıyla eksik. Sınıfta aynı şekilde ÖA 55)."

"Eğitim dersini bir de blok olarak işlemeyelim. Herkes uyuyor ya da yanındakiyle konuşmaya başlıyor. Ama bazı hocalarda dersin b itmesini bile istemiyor ÖA 58)."

"Sınıfımız kalabalık olduğu için ilgi dağınıklığı oluyor. Dersler sıkıcı geçiyor ÖA 61).

"Konular hızlı ve tam anlaşılmadan işleniyor öğrencinin sorumlu olduğu konular çok olmasından dolayı sinav sonuçları kötü ÖA 63).”

"Sekiz senedir bitiremedim. Beni biraksınlar ÖA 67)."

\section{Öğretmen Adaylarının Öğretim Elemanlarına İlişkin Görüşler}

Öğretmen adaylarının meslek derslerine giren meslek dersleri öğretim elemanlarına yönelik görüşlerinin yer aldığı temalar ve buna ilişkin olumlu, kısmen olumlu ve olumsuz görüşleri Tablo 2'de verilmiştir.

Tablo 2'de öğretmen adaylarının öğretim üyelerine yönelik görüşlerine bakıldığında, öğretmen adaylarının 14'ü öğretim elemanlarının bazılarının yetersiz olduğunu, 8'i genel olarak olumlu bulduklarını, 5'i dersleri ezber yöntemi ile işlediklerini, 4'ü sınav sorularını zor sorduklarını, 3'ü kötü örnek olduklarını, 3'ü uygulamaya yer vermediklerini, 2'i not konusunda cimri davrandıklarını, 2'i dersleri öğretmen merkezli işlediklerini, 1'i duyarsız davrandıklarını, 1'i konuları ödev olarak verdiğini, 1’i öğrencilere değer vermediğini, 1'i öğrenciyi dersten bıraktığı ifade ettikleri görülmüştür. 
Öğretmen adaylarının öğretim elamanlarına yönelik görüşleri olumlu, kısmen olumlu ve olumsuz görüşler olmak üzere üç tema altında ele alındığında, öğretim elamanlarına yönelik görüşlerin çoğunlukla kısmen olumlu ve olumlu olduğu görülmektedir.

Bazı öğretmen adaylarının meslek dersleri öğretim elamanlarına ilişkin görüşleri olduğu gibi aşağıya çıkarılmıştır:

Tablo 2.

Ögrretmen Adaylarının Öğretim Elamanlarına İlişkin Görüşler

\begin{tabular}{llll}
\hline Temalar & Kodlar & Öğrenciler & $\mathbf{n}$ \\
\hline Olumlu & Genel olarak olumlular & $1,21,36,37,38,39,40,61$ & 8 \\
\hline Kısmen & Bazıları yetersiz & $14,15,17,18,20,24,25,26,27,28,29,32$, & 14 \\
olumlu & & 46,58 & 5 \\
\hline \multirow{4}{*}{ Görüşler } & Dersleri ezber yöntemi ile işliyorlar & $31,32,45,53,62$ & 4 \\
& Sinav sorularını oldukça zor soruyorlar & $2,7,52,60$ & 3 \\
& Kötü örnek oluyorlar & $16,36,65$ & 3 \\
& Uygulamaya yer vermiyorlar & $19,53,62$ & 2 \\
& Derslenusunda öğretmen merkezli işliyorlar & 9,10 & 2 \\
& Duyarsız davranıorlar & 18,22 & 1 \\
& Konuları ödev olarak veriyorlar & 12 & 1 \\
& Öğrencilere değer vermiyorlar & 41 & 1 \\
& Öğrenciyi dersten birakıorlar & 27 & 1 \\
\hline & Toplam & & 45 \\
\hline
\end{tabular}

"Ölçme ve değerlendirme hocası ve öyt hocası hariç hiçbirinin verimli bir şekilde anlatılmadığını düşünüyorum. KPSS'ye görecemizi bildikleri halde yerinden kalkmayan kitabı okuyan hocalarımız yetmezmiş gibi sınavda en ince ayrıntıyı soran hocalarımız oldu ÖA 2)."

"Fakültemizdeki bazı hocaları yetersiz buluyorum kısacası etkili, yeterli bir eğitim alamıyoruz burada.

Resim öğretmenliği diğer öğretmenlikler kadar kutsal bir meslek ÖA14).”

"Son sınıfta derslerimize giren eğitim hocalarımızın dersleri verimli geçirmediklerini düşünüyorum ÖA 17)."

"Her dönem farklı eğitim dersi farklı öğretmen gördük. Unutulanlar da var az çok hatırlananlar da ÖA21)."

"Alanında çok iyi olup dersi çok akıcı ve iyi anlatan hocalarımızın yanı sıra konunun dışına çıkıp uzun uzun konuşan, dersi sıkıcı hale getirip dikkatleri derse toplayamayan hocalar da var ÖA 26)."

"Hocalarımız hakkında oldukça sorunlarım var ÖA 30).

"Bu zamana kadar dersime giren hocaların hepsi girdikleri dersleri boş geçirmediler değerlendirdiler. Teşekkür ediyorum hepsine ÖA38)."

"Pek olumlu düşüncem yok. Çoğu hocamız bizi derste uyutuyor. Bunu desek onlara 'siz uyumaya hazırsınız' diye savunma yaparlar. Ancak durum ortada. Hocaların geneli yeniliğe ve öğrenciye karşı daha yumuşak olmaya karşı ÖA45)."

"Bu yıl okuduğum okul yönetimi dersinin hiçbir katkısını görmedim ve 4 yıldır almadığım en düşük notu aldım. Tamamen sorulardan ve öğretme kaynaklı ÖA 52)."

"Eğitim derslerinden bazıları zaten ağır hoca da iyi etkili verimli bir şekilde anlatamayınca daha da ağırlaşıyor ÖA58)."

"Hocalarımız güzel eğitim veriyor fakat dersler öğrenci tarafindan anlaşılmadan geçiliyor ÖA61)."

"Bir ders saatine bir döneni sığdırmaya çalışan öğretmenlerimiz sayesinde hiçbir şey anamıoruz ÖA 65)."

"Sınavda en ince ayrıntıyı soran hocalarımız oldu. Eğitim derslerini sadece dershanede öğrendik ÖA2):"

"Ancak sınav zamanı sorulan soruların çoğunu ilk kez sınavda görüyoruz. Dersle basit sınavlar sor ÖA 7)".

"Eğitim olarak iyi ders aldık ama sınıf geneli kötü aldığı için haksızlık yapıldı ÖA 10)."

"Etkili bir eğitim ve öğretim alamadık. Baştan savma ve gereksiz etkileşimlerde bulunulmuştur. Öğrenci merkezli yerine hoca merkezli olmuştur ÖA 22)."

"Bazı derslerin işleniş tarzı bakımından anlamakta güçlük çekiyorum ve daha sora sınavlara çalışırken çok zorlanıyorum açıkçası ÖA 31)." 
"Dört sene boyunca bu derslere verilen önemin yarısı bize verilseydi belki bu derslere bakış açımız daha farklı olacaktı ÖA41)."

"Geleneksel ders işleyiş anlayışından yıldık sıkıldık. Farklı bir metot bulunmalı. Derste uyumak istemiyoruz. Ayrıca ezbere dayalı eğitim cabası ÖA 45)."

"Okul yönetimi dersi çok verimli bir ders olmadı. Sınıf ilgisiz hocamız da kitaptan anlattırıp öğrencilere artı koyuyordu. Arkadaşlarımızdan dinlememiz verimli olmadı ÖA 53).”

\section{Sonuç ve Tartışma}

$\mathrm{Bu}$ araştırmada, güzel sanatlar eğitimi bölümü öğrencilerinin, öğretmenlik meslek dersleri ve bu dersleri yürüten öğretim elemanlarına yönelik görüşlerinin bir değerlendirilmesi yapılmıştır. $\mathrm{Bu}$ amaçla güzel sanatlar eğitimi fakültesinde öğrenim gören resim ve müzik bölümü öğrencileriyle görüşme yapılmıştır. Elde edilen bulgular tartışılmış ve bazı sonuçlar elde edilmeye çalışılmıştır. $\mathrm{Bu}$ sonuçlara dayalı olarak bazı önerilerde bulunulmuştur.

Öğretmen adaylarının çoğunluğunun (34) meslek derslerine ilişkin olumlu bir görüş içinde olmadıkları, buna karşın bir kısım öğretmen adayının (28) olumlu görüş içinde oldukları görülmüştür. Görüşlerine başvurulan öğretmen adaylarının büyük bir kısmı, meslek derslerinin verimli olmadığını, dersleri olumlu bulmadıklarını, derslerden bir yarar görmediklerini, derslerin yeterli olmadığını, bu derslerin kaldırılması gereken derslerden olduğunu, dersi anlayamadıklarını, kendisine bir katkısının olmadığını, başaramayacağı derslerden olduğunu, konuların çok ve çok ayrıntılı olduğunu belirterek, derse karşı olumsuz görüşlerini ifade etmişlerdir. Öğretmen adaylarının çoğunluğunun meslek derslerine yönelik görüşleri olumludur. Öğrenciler derslerin genel olarak verimli geçtiğini ve derslerin önemli olduğunu belirtmişlerdir. Ancak bu görüşe katılmayan öğrenciler de bulunmaktadırlar. Oysa ögretmen olacak bireylerin mesleğin odağında bulunan meslek derslerini mesleğin icrası yönünden daha bir heyecanla takip etmeleri, kabullenmeleri gerekirdi.

Aksine, mesleğin icrasında en önemli belirleyicilerinden birisi olan görüşlerin olumsuzluğu söz konusudur. Tutumların ögretmenin mesleği etkili olarak icra etmelerine yardım eden hususların başında gelmektedir (Erdem, Gezer ve Çokadar, 2005). Bu kapsamda yapılacak iyileştirici çalışmalar, ögretmen adaylarının meslek derslerine karşı olumsuz tutumlarını yeniden olumluya dönüştürmesine yol açacağı umulur.

Literatürde bu araştırma sonuçlarıyla örtüşen araştırmalara rastlanmaktadır. Aladağ ve Buldur'ın (2016) araştırmasında, coğrafya öğretmen adaylarının bazıları meslek bilgisi derslerinin gereksiz olduğunu belirtmişlerdir. Özgüngör ve Kapıkıran (2008) güzel sanatlar öğrencilerinin meslek derslerine karşı tutumlarını diğer bölümlere göre düşük bulmuşlardır. Diğer yandan, Terzi ve Tezci'nin araştırmasında (2007) öğrencilerin meslek derslerine yönelik tutumlarını yüksek bulmuşlardır. Bulut'a (2009) göre, öğretmen adaylarının öğretmenlik mesleğine yönelik görüşleri olumlu bulunmuştur

Öğretmen adaylarının büyük bir kısmı (37) meslek dersi veren öğretim elemanlarını uygulamaları yönünden olumsuz olarak değerlendirirken, az bir kısmı da (8) olumlu olarak değerlendirmişlerdir. $\mathrm{Bu}$ konuda görüşlerine başvurulan öğretmen adaylarının büyük bir kısmı, öğretim elemanlarının bazılarının yetersiz olduğunu, dersleri ezber yöntemi ile işlediklerini, sınav sorularını zor sorduklarını, kötü örnek olduklarını, uygulamaya yer vermediklerini, not konusunda cimri davrandıklarını, dersleri öğretmen merkezli işlediklerini, duyarsız davrandıklarını, konuları ödev olarak verdiklerini, öğrencilere değer vermediklerini, öğrenciyi dersten bıraktıklarını ifade ederek öğretim elemanlarına ilişkin olumsuz görüş belirtmişlerdir. Öğretmen adaylarının az bir kısmı da, öğretim elemanlarını genel olarak olumlu bulduklarını belirtmişlerdir. Öğretmen adayları öğretim elemanlarını genel olarak olumsuz yönü ile değerlendirmişlerdir. Oysa öğretim elemanlarının, öğretmen adaylarınca olumlu olarak değerlendirmesi beklenirdi. Çünkü öğretim elemanları, öğrencilerin meslek derslerine yönelik tutumunu etkileyen önemli hususlardan birisi olarak görülmektedir. Dolayısıyla da böyle olmak durumundadir.

Öğretmen adayları iyi bir öğreticide bulunması gereken özellikleri; alana hâkim, genel öğretim yeterliklerine sahip, iyi iletişim kuran, doğru yöntem, strateji ve araç kullanma becerisine sahip, bilginin nasıl aktarılacağını bilen, öğrencilerle işbirliği kurabilen kişiler olarak tanımlamaktadırlar (Şen ve Erişen, 2002: 114). Öğretim elamanları, meslek derslerini öğrencilere sevdirebilecekleri gibi onların derslere karşı ilgilerinin azalmasına zemin de hazırlayabilirler. Diğer taraftan öğretim 
elemanları, öğretmen adayları için birer rol model görevi üstlenmiş olduklarından, tüm davranışlarında bu bilinçle hareket etmelidirler. Kısaca öğretim elemanı nasıl bir öğretmen görmek istiyorsa, öğretmen adaylarına da öyle yetiştirmelidir.

Literatüre bakıldığında, Kumral (2009) araştırmasında, öğrencilerin öğretim elemanlarına yönelik algılarını olumsuz bulunmuştur. Aynı araştırmada öğrenciler, öğretim elemanlarının iletişim, sevgi ve saygı gibi özelliklerinin yetersizliklerinden yakınmışlardır. Bayram (1992), Deryakulu, (1992), Bolat (1992) ve Erdoğan'ın (1990) araştırmalarında da öğretim elamanları olumsuz olarak değerlendirilmiştir. Aksu, Çivitçi ve Duy’un (2008) araştırmasında birinci öğretim öğrencileri öğretim elemanlarını olumsuz değerlendirirken, özel yetenekle öğrenci alan (Güzel sanatlar gibi) bölüm öğrencileri daha olumlu değerlendirmişlerdir. Türkoğlu (1993) ve Yüksel'in (2004) araştırmalarında, öğretim elemanları kendilerini yeterli görürken, öğrenciler öğretim elemanlarını yetersiz değerlendirmişlerdir.

Bu sonuçlara dayalı olarak mesleki ihtiyaç analizleri yapılmalı ve öğrencilerin meslek derslerine karşı ilgisizlik nedenleri araştırılmalıdır. Bu ilgisizliğin önemli nedenlerinden birisinin ve en önemlisinin öğretim elamanları olduğu gerçeğinden hareketle meslek derslerine giren öğretim elemanların rol model olmalı konusunda çalışmalara yer verilmelidir. Bazı üniversitelerde "Eğiticilerin Eğitimi" gibi buna benzer çalışmalar yapılmaktadır. Farklı fakültelerde benzer çalışmalar yapılarak sonuçları karşılaştırılmalıdır.

\section{Kaynakça}

Aksu, M. B., Çivitçi, A., \& Duy, B (2008). Yükseköğretim öğrencilerinin öğretim elemanlarının ders uygulamaları ve sınıf içi davranışlarına ilişkin görüşleri. Ínönü Üniversitesi, Eğitim Fakültesi Dergisi, 9(16), 17-42.

Akyüz, Y. (1989). Türk eğitim tarihi. Ankara Üniversitesi Eğitim Bilimleri Fakültesi Yayınları, Ankara.

Aladağ, C., \& Buldur, D. (2016). Coğrafya öğretmen adaylarının alan ve meslek bilgisi derslerine dair görüşleri. IJOESS, 7(25), 70-86.

Aydın, R. ve Sağlam, G. (2012). Öğretmen adaylarının öğretmenlik mesleğine yönelik tutumlarının belirlenmesi. Türk Ĕ̈itim Bilimleri Dergisi, 10(2), 257-294.

Bayram, H. (1992). Ĕ̈itim yüksekokullarında ögretim elemanı - ögrenci iletişimi. (Yayımlanmamış yüksek lisans tezi), Gazi Üniversitesi, Sosyal Bilimler Enstitüsü, Ankara.

Bogdan, R. C., \& Biklen, S.K. (1998). Qualitative research for education: an introduction to theory and methods. (3rd ed.). Boston, MA: Allyn and Bacon.

Bolat, S. (1990). Yükseköğretimde ögrretim elemanı - öğrenci iletişimi, Yayımlanmamış Yüksek Lisans Tezi, Hacettepe Üniversitesi, Sosyal Bilimler Enstitüsü, Ankara.

Bozdoğan, A. E., Aydın, D., \& Yıldırım, K. (2007). Öğretmen adaylarının öğretmenlik mesleğine ilişkin tutumları. Ahi Evran Üniversitesi Kırşehir Eğitim Fakültesi Dergisi (KEFAD), 8(2), 83-97.

Bursal, M., \& Buldur, S. (2016). İlköğretim öğretmen adaylarının meslek tercih nedenleri ve Geleceklerine yönelik beklentileri: karşılaştırmalı bir analiz. Abant İzzet Baysal Üniversitesi Ĕ̈itim Fakültesi Dergisi, 16(2), 351-376.

Buyurgan, S. (2007). Eğitim fakülteleri resim-iş eğitimi ana bilim dalı öğrencilerinin aldıkları eğitimöğretime yönelik görüş ve beklentileri, Türk Ĕgitim Bilimleri Dergisi, 5(4), 657-677.

Çelikten, M., Şanal, E., \& Yeni, L. (2005). Öğretmenlik mesleği ve özellikleri. Sosyal Bilimler Enstitüsü Dergisi, 19(2), 207-237.

Çetin, F. (2009). Eğitim fakültesi öğrencilerinin öğretmenlik meslek bilgisi derslerine yönelik tutumları, Gazi Üniversitesi Endüstriyel Sanatlar Eğitim Fakültesi Dergisi, 25, 58-64.

Creswell, J.W. (2002). Educational research: planning, conducting, and evaluating quantitative and qualitative research. Upper Saddle River, New Jersey: Merrill Prentice Hall.

Deryakulu, D. (1992). Öğretim elemanı - ögrrenci arası iletişimde istenilen ögretim elemanı davranışlarının gösterilmesini engelleyen faktörler. (Yayımlanmamış yüksek lisans tezi), Ankara Üniversitesi, Sosyal Bilimler Enstitüsü, Ankara.

Ekici, G. (2008). Öğretmen adaylarının öğretmenlik meslek bilgisi derslerine yönelik tutumları ile öğrenme biçimlerinin değerlendirilmesi. Yüzüncü Yll Üniversitesi, Eğitim Fakültesi Dergisi. 5(1), 111-132. 
Erdem A. R., Gezer, K., \& Çokadar, H. (2005). Ortaöğretim fen-matematik ve sosyal alanlar öğretmenliği tezsiz yüksek lisans öğrencilerinin öğretmenlik mesleğine ilişkin tutumları, XIV. Ulusal Ĕgitim Bilimleri Kongresi. 28-30 Eylül, Kongre Kitabı I. Cilt, 471-477, Denizli

Gül, İ. (2017). The relationship between teacher candidates' attitudes towards teacher credentialing courses and instructor behavior, Universal Journal of Educational Research, 5(12), 2274-2285, DOI:10.13189/ujer.2017.051218.

Iş1kgöz, E., Dinçer, N., \& Kılınç, Z. (2016). Beden eğitimi öğretmen adaylarının öğretmenlik meslek bilgisi dersleri ile alan bilgisi ders başarıları arasındaki ilişkinin incelenmesi (batman üniversitesi örneği). Yaşam Bilimleri Dergisi, 6(2/1),338-346.

Atik Kara, D., \& Sağlam, M. (2014). Öğretmenlik meslek bilgisi derslerinin öğrenme-öğretme sürecine yönelik yeterliklerinin kazandırılması yönünden değerlendirilmesi. Eğitimde Nitel Araştırmalar Dergisi, 2(3), 28-86. DOİ: 10.14689/issn.2148-2624.1.2c3s2m

Köksal, N. (2008). Öğretmenlik mesleği genel yeterliklerinin öğretmen, müdür ve bakanlık yetkilileri tarafindan değerlendirilmesi. Pamukkale Üniversitesi Ĕ̈itim Fakültesi Dergisi, 23(1), 36-46.

Kumral, A. (2009). Öğretmen adaylarının öğretim elemanlarının davranışlarına yönelik algıları, Pamukkale Üniversitesi Ĕ̈itim Fakültesi Dergisi, Sayı: 25, 92-102.

MEB (1973). Milli Eğitim Temel Kanunu. Resmi Gazete: Tarih: 24.6.1973, Say1: 14574.

Özgüngör, S., \& Kapıkıran, Ş. (2008). Güzel sanatlar eğitimi öğrencilerinin öğretmenlik meslek bilgisi derslerine ilişkin motivasyon ve başarı düzeyleri. Pamukkale Üniversitesi Eğitim Fakültesi Dergisi, 23(1), 47-60.

Şen, H.Ş., \& Erişen, Y. (2002). Öğretmen yetiştiren kurumlarda öğretim elemanlarının etkili öğretmenlik özellikleri, G. U. Gazi Ĕ̈itim Fakültesi Dergisi, 22(1), 99-116.

Taşkın, Ç.H., \& Hacıömeroğlu, G. (2010). Meslek bilgisi derslerinin öğretmen adaylarının profesyonel gelişimindeki önemi. Pamukkale Üniversitesi Ĕ̈itim Fakültesi Dergisi, 28, 165-174.

Terzi, A. R., \& Tezci, E. (2007). Necatibey eğitim fakültesi öğrencilerinin öğretmenlik mesleğine ilişkin tutumları. Kuram ve Uygulamada Ĕ̈itim Yönetimi, 52,593-614.

Türkoğlu, A. (1993). Eğitim yüksekokulu program uygulamalarında karşılaşılan soranlar. Ĕ̆itim Bilimleri I. Ulusal Bildirileri (179-189). Ankara: Ankara Üniversitesi Eğitim Bilimleri \& Milli Eğitim Basımevi

Ünal, E., \&Şimşek, S. (2008). İlköğretim bölümü anabilim dallarında öğrenim gören öğretmen adaylarının mesleki benlik saygılarının çeşitli değişkenler açısından incelenmesi. İlkögretim Online, 7(1), 41-52.

Van Maanen, J. (1988).Tales of the field: on writing ethnography. Chicago: Univ. of Chicago Press.

Varış, F. (1988). Eğitimde program geliştirme. Ankara: Üniversitesi. Eğitim Fakültesi Yayınları.

Yıldırım, A., \& Şimşek H.( 2008). Sosyal bilimlerde nitel araştırma yöntemleri. Ankara: Seçkin Yayıncilik.

Y1lmaz, K., \& Altınkurt, Y. (2011). Göreve yeni başlayan özel dershane öğretmenlerinin kurumlarındaki çalışma koşullarına ilişkin görüşleri. Kuram ve Uygulamada Eğitim Bilimleri, $11(2), 635-650$.

Yüksel, S. (2004). Eğitim fakültesi öğrencilerinin öğretmenlik meslek bilgisi derslerine yönelik direnç davranışları, (Elektronik versiyon]. Kuram ve Uygulamada Ĕgitim Bilimleri, 4(1), 171-200.

Yüksel, S. (2009). Eğitim fakültesi öğrencilerinin öğretmenlik meslek bilgisi derslerine ilişkin görüşleri, Ankara Üniversitesi Eğitim Fakültesi Dergisi, 42(1), 435-455. 